\title{
State of the Salton Sea: A Science and Monitoring Meeting of Scientists for the Salton Sea
}

Open-File Report 2017-1005 
Cover. Salton Sea. Photograph by Douglas A. Barnum, U.S. Geological Survey. 


\section{State of the Salton Sea: A Science and Monitoring Meeting of Scientists for the Salton Sea}

By Douglas A. Barnum, Timothy Bradley, Michael Cohen, Bruce Wilcox, and Gregor Yanega

Open-File Report 2017-1005 


\section{U.S. Department of the Interior SALLY JEWELL, Secretary}

\section{U.S. Geological Survey Suzette M. Kimball, Director}

\section{U.S. Geological Survey, Reston, Virginia: 2017}

For more information on the USGS - the Federal source for science about the Earth, its natural and living resources, natural hazards, and the environment—visit http://www.usgs.gov or call 1-888-ASK-USGS.

For an overview of USGS information products, including maps, imagery, and publications, visit http://www.usgs.gov/pubprod/.

Any use of trade, firm, or product names is for descriptive purposes only and does not imply endorsement by the U.S. Government.

Although this information product, for the most part, is in the public domain, it also may contain copyrighted materials as noted in the text. Permission to reproduce copyrighted items must be secured from the copyright owner.

Suggested citation:

Barnum, D.A., Bradley, T., Cohen, M., Wilcox, B., and Yanega, G., 2017, State of the Salton Sea-A science and monitoring meeting of scientists for the Salton Sea: U.S. Geological Survey Open-File Report 2017-1005, 20 p., https://doi.org/10.3133/ofr20171005.

ISSN 2331-1258 (online) 


\section{Acknowledgments}

The organizing committee would like to thank the Imperial Valley College and the University of California for providing meeting space in El Centro and Sacramento, California. Imperial Irrigation District provided financial support for the field trip preceding the State of the Salton Sea meeting. Peer review comments and suggestions were kindly provided by Dr. Katie Pine, University of California at Irvine, and Laura Valoppi, U.S. Geological Survey. Financial support for this work was provided by the Bureau of Reclamation, Lower Colorado River Office under Interagency Agreement R14PG00064, and the U.S. Geological Survey Pacific Region Office. 


\section{Contents}

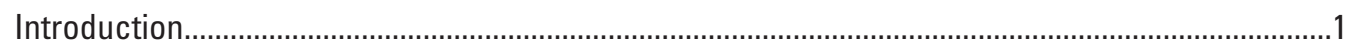

Goals and Objectives of Salton Sea Management ……….............................................................

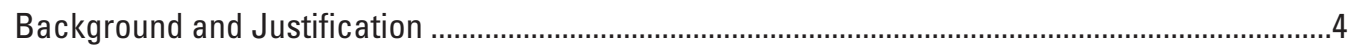

Organizing Committee and State of the Salton Sea Meeting Development ....................................

Managerial Meetings................................................................................................................ 10

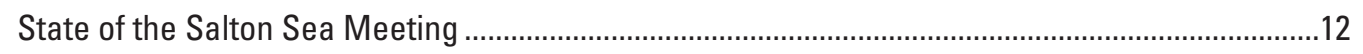

Synopsis of Conceptual Proposals ............................................................................................13

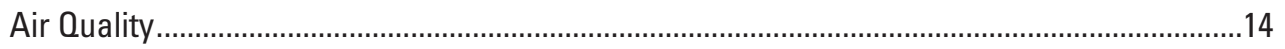

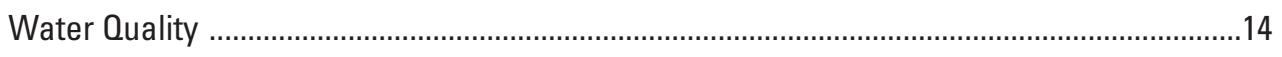

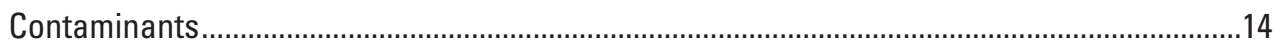

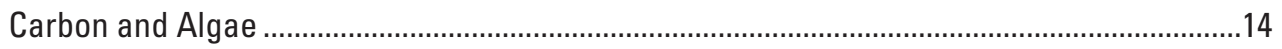

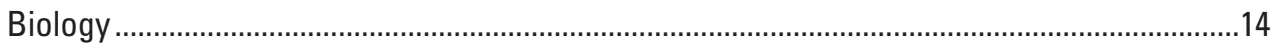

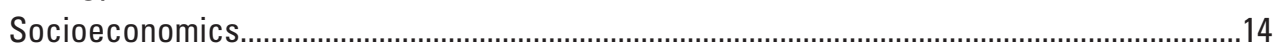

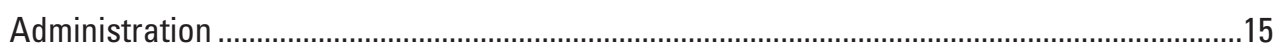

Recommendations for Support of an Effective Science and Monitoring Program .........................15

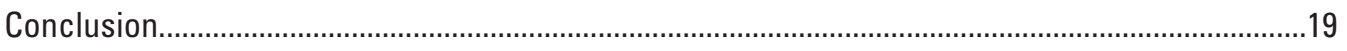

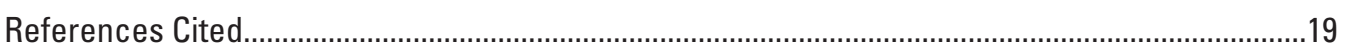

All appendixes can be downloaded at https://doi.org/10.3133/ofr20171005

\section{Appendix}

1. Notes from Meetings with Managers and Policy-Makers Addressing Gaps in Salton Sea Science, Fall 2014

2. State of the Salton Sea Workshop Participants and Working Groups

3. Agenda for State of the Salton Sea Workshop, September 8-10, 2014

4. Summary of Information Presented to Participants, Workshop Guidelines, and Proposal

5. Suggested Scientific Studies

6. Roles and Responsibilities

7. Strategic Science Plan 2000-Executive Summary

8. Salton Sea Ecosystem Monitoring and Assessment Plan-Executive Summary 


\section{Figures}

1. Graph showing chart of Salton Sea lake surface elevation from U.S. Geological

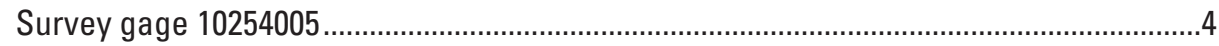

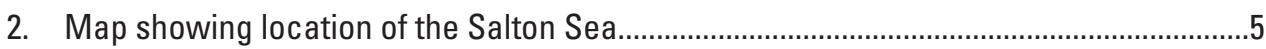

3. A, Map showing locations of bird-band recoveries for all birds banded the Salton Sea and recovered anywhere. $B$, Map showing locations of bird-band recoveries for birds banded elsewhere and recovered at the Salton Sea..........

4. Map of the Salton Sea modeling projection of No Action Alternative, indicating future exposed playa and lake level...........................................................................

5. Graph showing projected changes to salinity and lake surface elevation and effects on major aquatic biota.

\section{Tables}

1. Salton Sea management goals and objectives as stated by governing

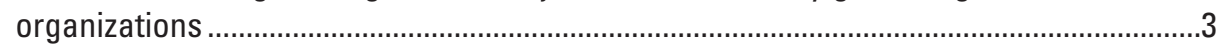

2. Organizational representation at the managerial meetings..............................................10

3. Summary of management needs and concerns regarding science and monitoring of the Salton Sea

4. Proposal title and estimated dollar value to conduct research/monitoring activities for the Salton Sea. .16

5. Recommendations for support of an effective science program for the Salton Sea 


\section{Abbreviations}

\begin{tabular}{|c|c|}
\hline AM & adaptive management \\
\hline C & carbon \\
\hline CDFG & California Department of Fish and Game (now California Department of Fish and Wildlife) \\
\hline CEP & Controlled Eutrophication Process \\
\hline CEQA & California Environmental Quality Act \\
\hline CIMIS & California Irrigation Management Information System \\
\hline CVWD & Coachella Valley Water District \\
\hline cyberinfrastructure & $\begin{array}{l}\text { equipment, software, and policies for collecting, storing, and distributing digital } \\
\text { information }\end{array}$ \\
\hline DO & dissolved oxygen \\
\hline DFW & California Department of Fish and Wildlife \\
\hline DMS & dimethyl sulfide \\
\hline drain water & surface and subsurface water from agricultural fields \\
\hline DWR & California Department of Water Resources \\
\hline EIR & Environmental Impact Report \\
\hline EIS & Environmental Impact Statement \\
\hline EPA & U.S. Environmental Protection Agency \\
\hline EPS & extracellular polymeric substance, a natural biopolymer form of organic matter \\
\hline ET & evapotranspiration \\
\hline FTE & full-time equivalent \\
\hline FTG & focused technical group \\
\hline GIS & geographic information system \\
\hline GPS & Global Positioning System \\
\hline GUI & graphical user interface \\
\hline HRT & hydraulic retention time \\
\hline $\mathrm{H}_{2} \mathrm{~S}$ & hydrogen sulfide gas \\
\hline IID & Imperial Irrigation District \\
\hline Kd & a partitioning coefficient value used in selenium modeling \\
\hline $\mathrm{km}$ & kilometer \\
\hline LCRB & Lower Colorado River Basin \\
\hline MAP & Monitoring and Assessment Plan \\
\hline MODFLOW & a USGS three-dimensional finite-difference groundwater model \\
\hline MWD & Metropolitan Water District of Southern California \\
\hline N & nitrogen \\
\hline NEPA & National Environmental Protection Act \\
\hline NGO & non-government organization \\
\hline $\mathrm{NH}_{3}$ & ammonia \\
\hline $\mathrm{NH}_{4}$ & ammonium \\
\hline NIWQP & National Irrigation Water-Quality Program \\
\hline NOx & nitrogen oxides \\
\hline$P$ & phosphorus \\
\hline
\end{tabular}




\section{Abbreviations-Continued}

\begin{tabular}{|c|c|}
\hline PEIR & Programmatic Environmental Impact Report \\
\hline PGPR & plant growth promoting rhizobacteria \\
\hline $\mathrm{pH}$ & a measurement of acidity or alkalinity from 0 to 14 \\
\hline playa & the exposed floor of a desert basin usually occupied by a shallow lake \\
\hline $\mathrm{PM}_{10} / \mathrm{PM}_{2.5}$ & particulate matter that will pass through a 10 or 2.5 micrometer filter \\
\hline $\mathrm{QA} / \mathrm{QC}$ & quality assurance/quality control \\
\hline QSA & Colorado River Quantification Settlement Agreement of 2003 \\
\hline Reclamation & Bureau of Reclamation \\
\hline Salton Basin & interchangeable phrase for the Salton Sink \\
\hline Salton Sink & $\begin{array}{l}\text { a terminal depression within the Salton Trough of southeastern California where water } \\
\text { collects }\end{array}$ \\
\hline Salton Trough & $\begin{array}{l}\text { an active tectonic pull-apart basin within the Imperial, Riverside, and San Diego Counties } \\
\text { of southeastern California }\end{array}$ \\
\hline SALSA2 & $\begin{array}{l}\text { a computer program developed to facilitate evaluation of alternatives in an uncertainty } \\
\text { framework. The model provides tools for the analysis of future hydrologic and salinity } \\
\text { conditions at the Salton Sea }\end{array}$ \\
\hline $\mathrm{SCH}$ & species conservation habitat project \\
\hline SDCWA & San Diego County Water Authority \\
\hline Se & selenium \\
\hline seiche & a standing wave in an enclosed or partially enclosed body of water \\
\hline SoSS & State of the Salton Sea Science meeting \\
\hline SSA & Salton Sea Authority \\
\hline SSC & Salton Sea Science Committee \\
\hline SSM & Salton Sea Model Army Corps of Engineers simulation model \\
\hline SSNWR & Sonny Bono Salton Sea National Wildlife Refuge \\
\hline SSP & Salton Sea Strategic Science Plan \\
\hline tail water & surface runoff water from agricultural fields \\
\hline tile water & subsurface runoff water from agricultural fields \\
\hline TDS & total dissolved solids \\
\hline TFF & trophic transfer function, a value used in selenium modeling \\
\hline TSS & total suspended solids \\
\hline UC & University of California \\
\hline USFWS & U.S. Fish and Wildlife Service \\
\hline USGS & U.S. Geological Survey \\
\hline
\end{tabular}




\title{
State of the Salton Sea: A Science and Monitoring Meeting of Scientists for the Salton Sea
}

\author{
By Douglas A. Barnum', Timothy Bradley², Michael Cohen ${ }^{3}$, Bruce Wilcox4, and Gregor Yanega ${ }^{2}$
}

\section{Introduction}

The Salton Sea (Sea) is an ecosystem facing large systemic changes in the near future. Managers and stakeholders are seeking solutions to the decline of the Sea and have turned to the scientific community for answers. In response, scientists gathered in Irvine, California, to review existing science and propose scientific studies and monitoring needs required for understanding how to retain the Sea as a functional ecosystem. This document summarizes the proceedings of this gathering of approximately 50 scientists at a September 8-10, 2014, workshop on the State of the Salton Sea (SoSS).

In 1997, a similar gathering of nearly 100 scientists and others in Palm Springs, Calif., yielded a number of scientific proposals establishing a foundation for a program of integrated science investigations. The 1997 workshop results were combined with recommendations from a U.S. Geological Survey (USGS) Tiger Team (Shipley and others, 1999), resulting in the eventual creation of a Strategic Science Plan (SSP) for the Salton Sea (Salton Sea Science Subcommittee, 2000). The vision from the 1997 workshop of an integrated and coordinated program of scientific investigations, embraced by the SSP, was implemented through the SSC and the USGS Salton Sea Science Office (Science Office). The integrated science program, mandated by the Salton Sea Reclamation Act of 1998 (Public Law 105-372) and spelled out in the SSP, directly led to an increased scientific understanding of the Salton Sea ecosystem. The workshop concluded that "rehabilitation of the Sea is essential and requires that current ills be rectified in a manner that allows the Sea to sustain social values of importance to the human populations of the Imperial and Coachella Valleys, as well as society in general" (U.S. Fish and Wildlife Service, 1997). The 2014 SoSS workshop built upon the foundations of the 1997 workshop, with particular emphasis on changes in the condition of the Sea and its environment in the intervening years.

Over the past five decades, investigations of the Salton Sea have addressed water quality, biological, recreation, and (or) economic issues at the Salton Sea (California Resources Agency, 2006, chap. 8). Many stakeholders believe that the Salton Sea has been "studied to death" (Claiborne, 1996). Although it is true that a great deal of research has been completed at the Salton Sea, much of it has been short term and focused on specific topics with little or no integration across science disciplines, time, and space. Additionally, there have been numerous attempts at resource management of the Salton Sea (previously referred to as restoration planning).

Study objectives have differed, but the main focus has generally been on methods to control the salinity and elevation of the Salton Sea (California Resources Agency, 2006, chaps. 1 and 4). Most investigations resulted in proposed plans to preserve the Salton Sea as a thriving fishery and recreational destination, and most of these plans addressed methods to preserve the "whole Sea." More recently, however, studies have recognized that maintaining a smaller Salton Sea should be considered, owing to declining inflows to the Salton Sea (California Resources Agency, 2006).

\footnotetext{
${ }^{1}$ U.S. Geological Survey

${ }^{2}$ University of California, Irvine

${ }^{3}$ Pacific Institute

${ }^{4}$ Imperial Irrigation District
}

Is this really "restoration"?

Ecological management involves an assumption that human intervention can reverse environmental degradation to a prior state of ecological health, integrity, and sustainability (Society for Ecological Restoration International, 2004). With implementation of the Quantification Settlement Agreement and other changes affecting inflows, it has become apparent to many managers and decisionmakers that meeting public expectations for a "whole sea fix" of the Salton Sea (Sea) may not be possible, and thus "restoration" is no longer an appropriate description for planning intent. Similarly, conservation of the Sea, which would involve preserving existing biodiversity of species while maintaining the habitat according to historical standards, is something no Salton Sea planning yet accomplishes. The goals of current planning efforts are broad, and no single plan has been

(continued on next page) 
agreed to by all parties setting forth specific management targets (for example, number of bird species, fish productivity, acres of habitat, water quality, contaminant levels, or dust emission levels). Providing scientific guidance and developing conceptual proposals is difficult, and a true adaptive management program is not attainable without a plan for management of the Salton Sea with defined and measurable goals.

Current plans for managing the Salton Sea have focused on the reality of diminished inflows and therefore a smaller lake in the future. Any planning strategy will aim to protect as much of the historical, biological, and physical functioning of the lake as is practical with significantly less water. In this sense, management of the entire Salton Sea is no longer an objective. The objective is to provide rehabilitation and management of resources or their functions to the greatest practical extent possible. This strategy is called Salton Sea resource management. Scientists at the State of the Salton Sea meeting developed proposals directed towards providing science to support any Salton Sea management plan. For the purpose of this document, "resource management" or simply "management" is used in place of the word "restoration," except in original excerpted documents found in appendixes.
Prior investigations considered hundreds of alternatives for managing Salton Sea salinity, nutrients, and water elevation. Some alternatives generated revenue to help pay for rehabilitating the Sea. These alternatives have been addressed in multiple studies, as summarized in chapters 1 and 4 of the "Salton Sea Ecosystem Restoration Program Draft Programmatic Environmental Impact Report” (California Resources Agency, 2006).

Although there have been multiple efforts to characterize the Salton Sea ecosystem and develop management plans, it was not until 1996 that a comprehensive and integrated research needs assessment was developed (U.S. Fish and Wildlife Service, 1997). The 1997 report captured the combined thinking of scientists and managers and identified several areas of scientific research that would be required for a fuller, more complete understanding of the Salton Sea necessary to undertake any management project. The report defined these broad categories of science as physical environment, biological environment, cultural resources, pathogens and diseases, and contaminants. These categories form the basic framework for all scientific investigations at the Salton Sea. Some science categories continue to receive greater emphasis because limited funding has required the prioritization of projects.

A Salton Sea Science Subcommittee (SSC) authorized by Public Law 105-372, representing a broad range of Federal, State, local, and other stakeholder interests, endorsed a long-range Strategic Science Plan for the Salton Sea (Salton Sea Science Subcommittee, 2000). Whereas the U.S. Fish and Wildlife Service 1997 report established the types of science needed, the SSP further established the governing processes and expectations of how this science program should be conducted. The SSP provided the framework for scientific investigations and remains the source for identifying how scientific studies should be undertaken to better understand the Salton Sea ecosystem. Based substantially on the U.S. Fish and Wildlife Service (1997) analysis of science needs, and in consultation with many stakeholders, the SSC authorized and funded a number of initial reconnaissance-level projects.

The structure of this SoSS document follows the basic framework of the U.S. Fish and Wildlife Service 1997 report, placing emphasis on physical environment (air and water quality), biological environment (birds, fish, invertebrates, carbon, and algae), contaminants, and socioeconomics.

The SoSS meeting in 2014 was convened to build upon previous scientific efforts and to provide guidance to managers on what experts believe are the most critical science needs going forward. Experts were invited to participate in the SoSS meeting based on a review by the organizing committee of individuals with subject area expertise and experience working at the Salton Sea or in similar environments. The SoSS organizing committee presented a synopsis of known science to the gathered scientists, who were then tasked to evaluate the completeness of that science and make recommendations for science needs to fill information gaps. Participants were challenged to think and act independently of their organizational affiliation in order to generate conceptual proposals designed to address scientific and monitoring concerns identified by the managerial meeting participants.

Reconnaissance investigations identified and funded by the Salton Sea Science Subcommittee

- Survey of Algal Toxins in the Salton Sea

- Avifauna of the Salton Sea: Annual Phenology, Numbers, and Distribution

- Fisheries Biology and Fish Ecology of the Salton Sea

- Salton Sea Desert Pupfish Investigations

- Reconnaissance of the Biological Limnology of the Salton Sea

- Limnological Assessment of the Salton Sea, Riverside and Imperial Counties

- Survey of Selected Microbial Pathogens in the Salton Sea

- Environmental Reconnaissance of the Salton Sea: Sediment Contaminants

- Baseline Reconnaissance Vegetation Mapping of the Salton Sea 


\section{Goals and Objectives of Salton Sea Management}

Federal, State, and local governing organizations with an interest in developing management plans have stipulated a number of goals and objectives (table 1). These goals are obviously broad, and there is no single plan agreed to by all parties setting forth specific management targets (for example, number of bird species, fish productivity, acres of habitat, and water quality). Thus, providing scientific guidance and developing conceptual proposals is difficult without identifiable resource management goals. Without a resource management plan, it is not possible to design methods for evaluating effectiveness of planned management actions or implement any type of adaptive management plan.

Scientists at the SoSS meeting were directed to develop conceptual proposals amenable to the broad goals and objectives outlined in table 1 , as well as ones that could be applicable to any future Salton Sea resource management plan.

The USGS Science Office was established by the U.S. Department of the Interior in 2000 to function as an independent and unbiased advisor on Salton Sea science activities initiated as a result of PL 105-372, which was derived from the U.S. Fish and Wildlife Service 1997 workshop and actions of the SSC related to Salton Sea management (Salton Sea Science Subcommittee, 2000). Since its establishment, the Science Office has been integral to building a more complete understanding of the science of the Salton Sea through convening expert workshops (for example, Salt Deposition, Air Quality, Water Quality, Selenium, Eutrophication, Shallow Saline Habitat), coordinating expert reviews of management proposals, participating in California's 2003-7 Programmatic Environmental Impact Report (California Resources Agency,
2006), and providing staff to serve as chair of the State of California's Salton Sea Science Committee. The Science Office also led the development of a plan outlining science and monitoring needs for the Salton Sea (Case and others, 2013).

The scientific investigations that emerged from the 1997 Salton Sea workshop provided a wealth of new and interrelated scientific understandings of how the Sea functions (Barnum and others, 2002; Hurlbert, 2007; Hurlbert, 2008). Almost 20 years later, there is a clear need to build upon those concentrated scientific investigations. Unresolved issues include the need for monitoring efforts to fill the gaps in our knowledge, which suffer from a lack of funding. Furthermore, the Sea has changed dramatically since 1997, with increasing salinity, declining inflows, reductions in the quantity and quality of shoreline and island habitats, further declines in dissolved oxygen concentrations and invertebrate populations, and increased exposure of sediments as the Sea recedes (fig. 1). Additionally, the rate of change for all of these issues at the Salton Sea will increase significantly after 2017, due to the impacts of a major water transfer combined with the termination of supplemental mitigation water. Documenting current conditions will provide an invaluable baseline for understanding future changes. Addressing these gaps in knowledge is critical to the success of any Salton Sea management effort. Limited monitoring of the Sea and associated management efforts and lack of appropriate guidance for these management efforts hinder the ability of scientists and managers to adequately evaluate success or failure of projects.

This document reports the results of a meeting of scientists and managers convened over a 3-day period in Irvine, Calif., in 2014 to (1) review the science conducted to date, (2) assess gaps in our knowledge, and (3) make recommendations for immediate and near-future science and monitoring needs, including anticipated funding requirements.

Table 1. Salton Sea management goals and objectives as stated by governing organizations.

\begin{tabular}{|c|c|}
\hline Organization and source & Goals and objectives \\
\hline $\begin{array}{l}\text { Federal } \\
\text { Public Law 105-372 } \\
\text { Salton Sea Reclamation Act of } 1998\end{array}$ & $\begin{array}{l}\text { - Continued use of the Salton Sea as a reservoir for irrigation drainage. } \\
\text { - Reduce and stabilize the overall salinity of the Salton Sea. } \\
\text { - Stabilize the surface elevation of the Salton Sea. } \\
\text { - Reclaim in the long term, healthy fish and wildlife resources and their habitats. } \\
\text { - Enhance the potential for recreational uses and economic development of the Salton Sea. }\end{array}$ \\
\hline $\begin{array}{l}\text { State of California } \\
\text { California Resources Agency, } 2006 \\
\text { Executive Summary Salton Sea } \\
\text { Ecosystem Restoration Draft Programmatic } \\
\text { Environmental Impact Report }\end{array}$ & $\begin{array}{l}\text { - Restoration of long-term stable aquatic and shoreline habitat for the historic levels and } \\
\text { diversity of fish and wildlife that depend on the Salton Sea. } \\
\text { - Elimination of air quality impacts from the restoration project. } \\
\text { - Protection of water quality. }\end{array}$ \\
\hline $\begin{array}{l}\text { Salton Sea Authority } \\
\text { (http://saltonsea.ca.gov/) }\end{array}$ & $\begin{array}{l}\text { - Restore healthy habitat. } \\
\text { - Revitalize economy. } \\
\text { - Retain agricultural drain. } \\
\text { - Stabilize salinity. } \\
\text { - Preserve shoreline and sea elevation. }\end{array}$ \\
\hline
\end{tabular}




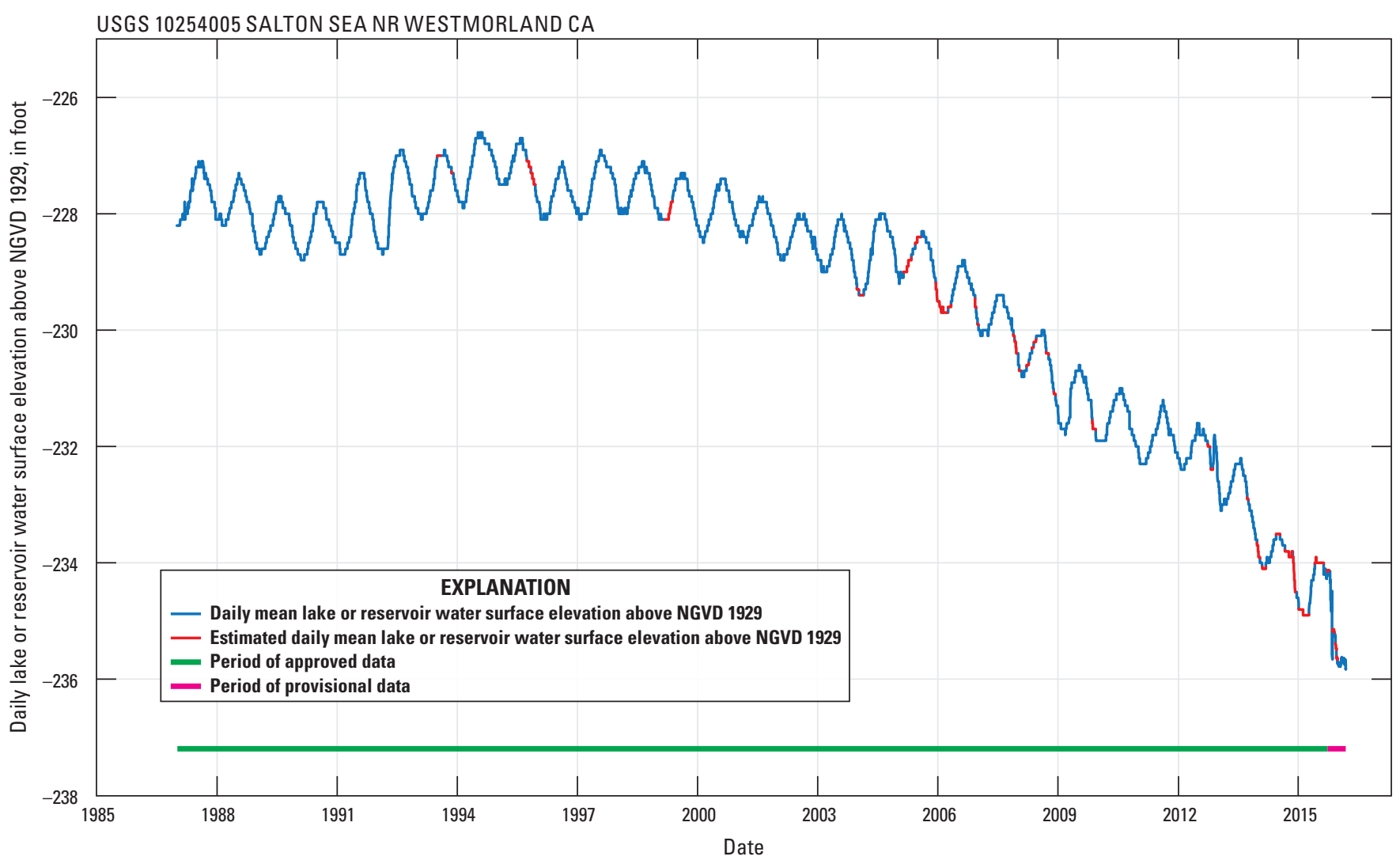

Figure 1. Chart of Salton Sea lake surface elevation from U.S. Geological Survey gage 10254005.

\section{Background and Justification}

The Salton Sea is California's largest lake (fig. 2). The Sea provides critical habitat for migratory birds and is an important cultural, economic, and recreational resource. The Salton Sea is a critical stop for migratory birds on the Pacific Flyway. Over 400 species of birds, including 80 percent of the western population of White Pelicans and 20 species of concern, have been observed at the Sea. The Salton Sea lies at a critical geographic juncture for migratory birds (fig. $3 A, B$ ). Actions that may affect migratory birds and the wetlands they use are of high interest because of the loss of more than 90 percent of California's historic wetlands. Regional, national, and international issues are associated with management of the Salton Sea because of its influence on air quality, potential selenium contamination, and habitat for migratory birds. Water transfers from agricultural uses in the Imperial Valley to municipal uses in coastal southern California authorized by the 2003 Quantification Settlement Agreement (QSA; Coachella Valley Water District and others, 2002) will decrease agricultural return flow to the Salton Sea and result in loss of aquatic and wetland habitat, increased salinity, a lower water elevation, and degraded air quality if no action is taken (fig. 4). By reducing the amount of water applied to agricultural fields in the Imperial Valley, the QSA effectively reduces the amount of water flowing into the Salton Sea. In return, the QSA stipulates that Imperial Irrigation District (IID) must make "mitigation water" available to the Salton Sea to reduce the impacts of the water transfer on the Salton Sea. This stipulation of the QSA, negotiated to allow time to develop a comprehensive plan for addressing Salton Sea management, ends on December 31, 2017, after which mitigation water will no longer be a requirement. In a scenario in which nothing is done to manage diminishing inflows, increasing salinity, and other issues (termed a No Action Alternative), then the Sea level is expected to decline rapidly after mitigation water termination (California Resources Agency, 2006). Other external factors will also affect the Sea level, such as declining inflows from Mexico, increasing urbanization, changing agricultural practices, more efficient irrigation methods, and climate change (California Resources Agency, 2006). Additionally, if a No Action Alternative is adopted, the volume of water flowing into the Sea will decrease substantially, the Salton Sea's surface elevation will drop by 20 feet or more, its volume will decrease, and salinity will triple. One hundred square miles of lakebed will be exposed to the region's blowing winds, and dust emissions will increase (fig. 5; Cohen and Hyun, 2006). 


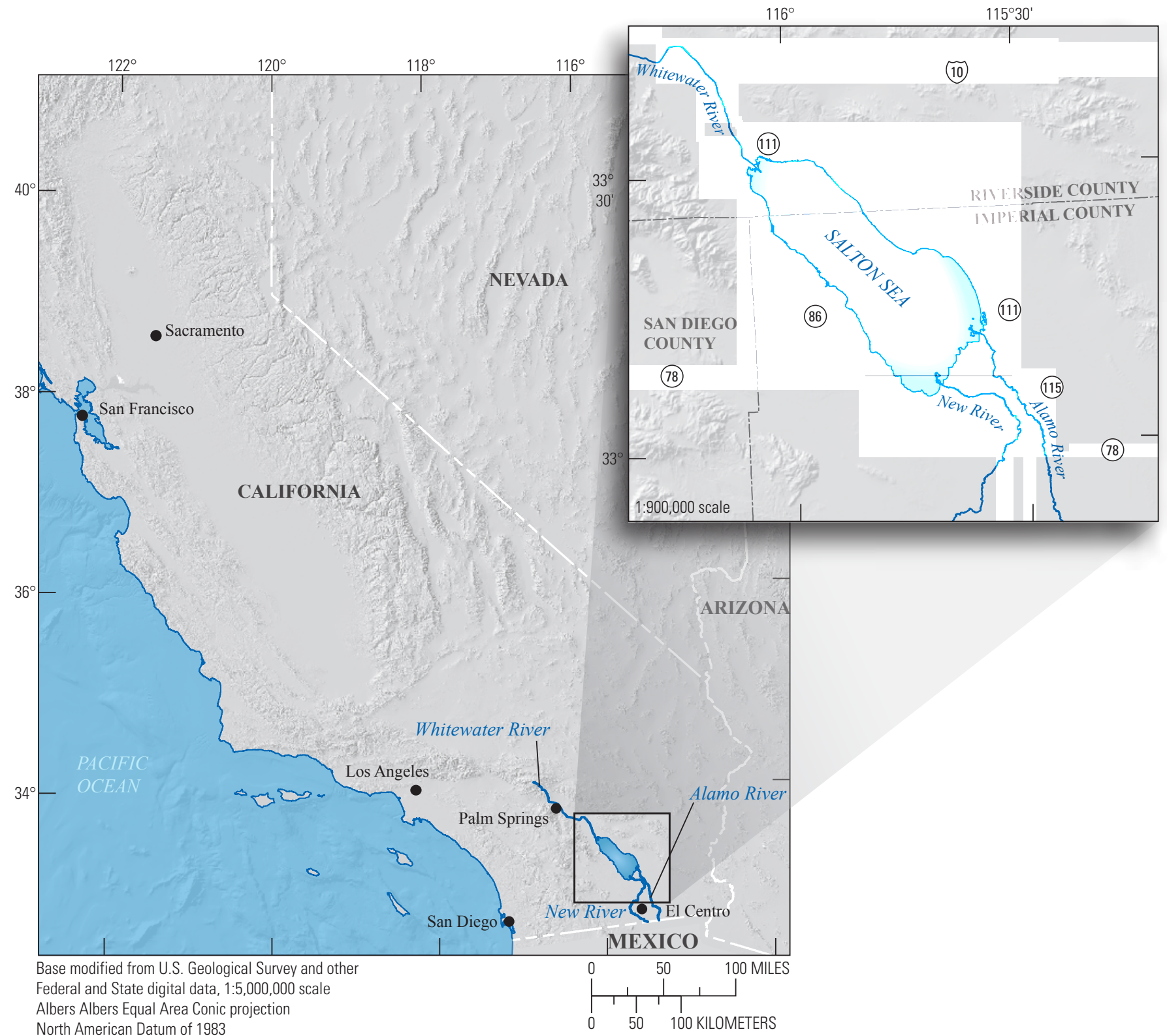

Figure 2. Map showing location of the Salton Sea. 

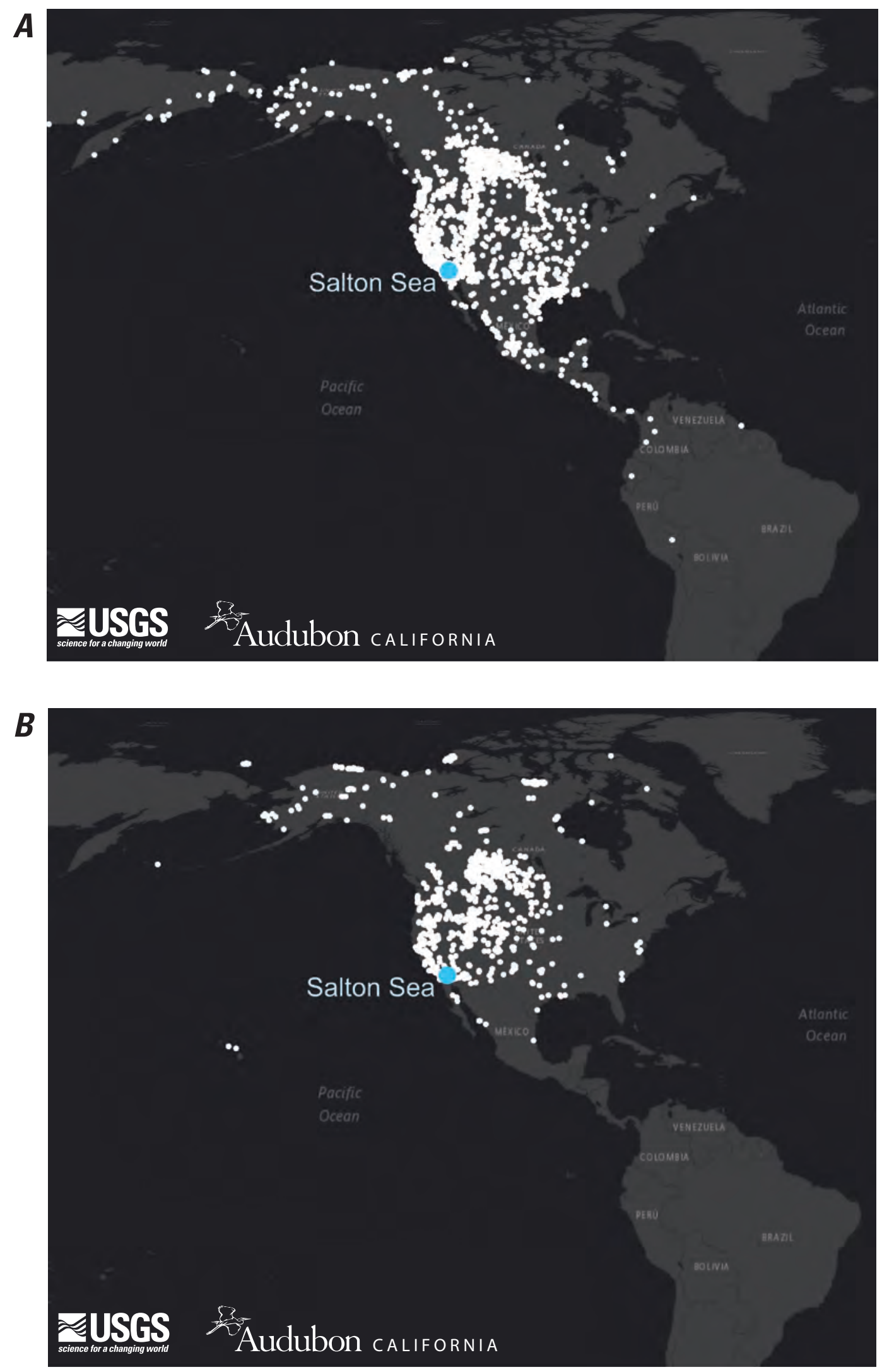

Figure 3. A, Map showing locations of bird-band recoveries for all birds banded at the Salton Sea and recovered anywhere. The data display depicts the Salton Sea as a point of origin for birds. B, Map showing locations of bird-band recoveries for birds banded elsewhere and recovered at the Salton Sea. This data display depicts the Salton Sea as a destination point for birds. 


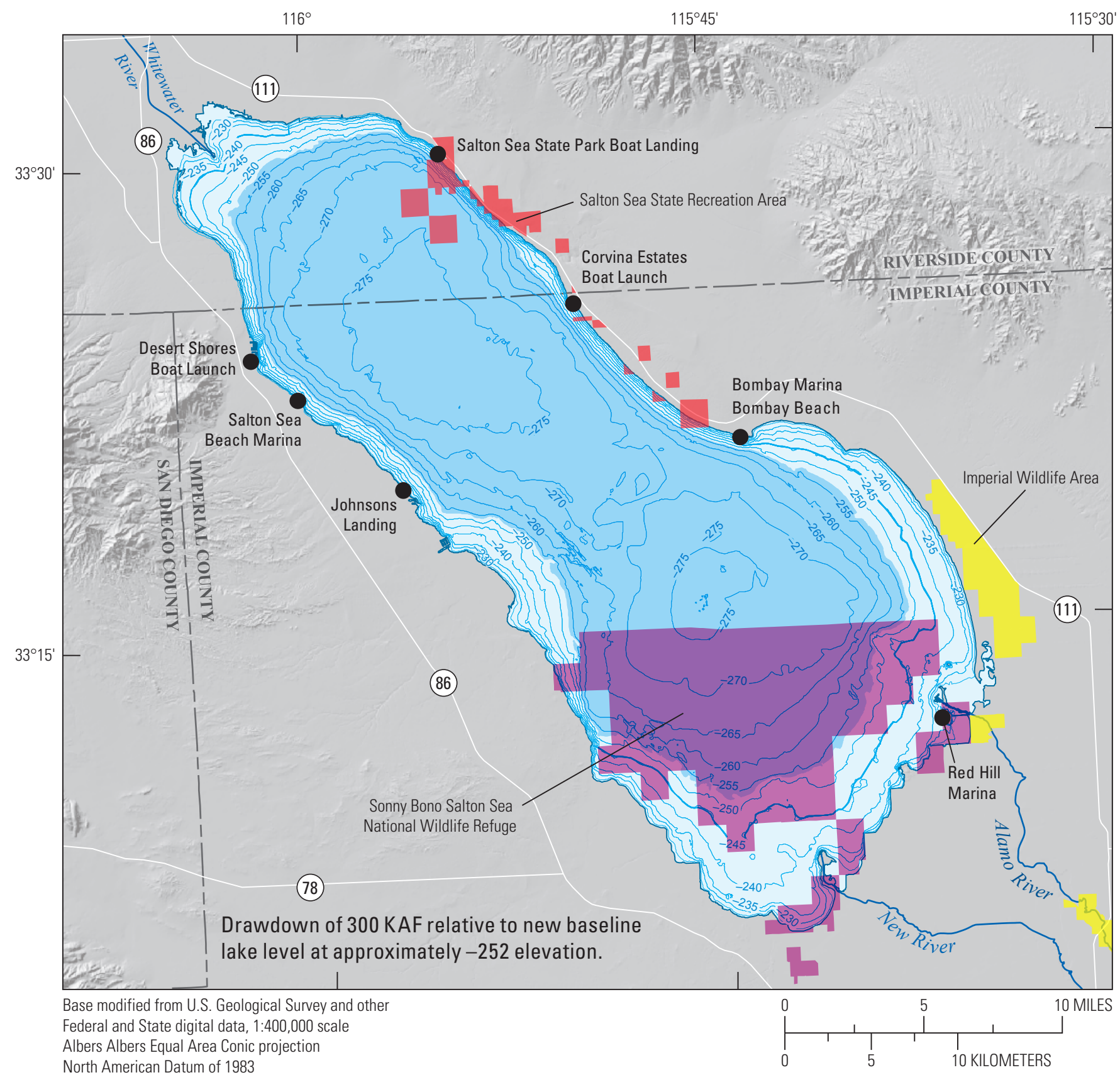

Figure 4. Map of the Salton Sea modeling projection of No Action Alternative, indicating future exposed playa and lake level. White region is indicative of playa exposed as water recedes from -232 feet (below sea level) to No Action Alternative projected level of -252 feet (below sea level). Magenta overlay indicates approximate footprint of the Sonny Bono Salton Sea National Wildlife Refuge. Data from University of Redlands Salton Sea Database Program. KAF, thousand acre-feet. 


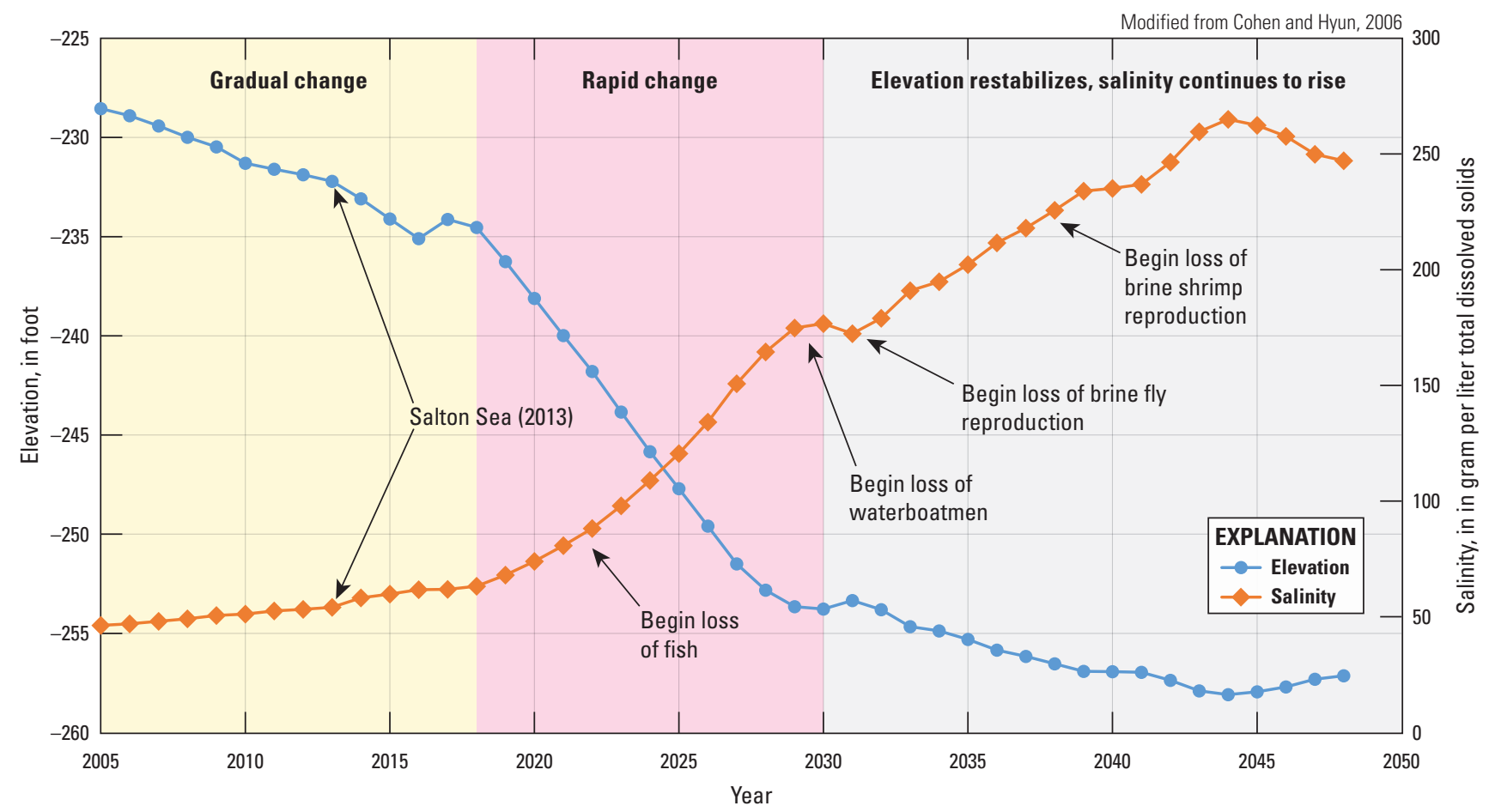

Figure 5. Projected changes to salinity and lake surface elevation and effects on major aquatic biota. Orange zone indicates current period of gradual change. Pink zone indicates period of rapid change owing to increasing water transfer amounts to urban southern California and elimination of mitigation water sanctioned by the Quantification Settlement Agreement (OSA).

Now that the "big picture" science has mostly been accomplished, managers and scientists can focus on science designed to generate a better understanding of these broad findings and fill in identified gaps in our knowledge; this would allow better modeling of system dynamics and a better understanding of unknown effects of rehabilitation projects. Scientists in previous workshops have identified issues such as hydrogen sulfide, thermoclines, water mixing regimes, and potential fatal flaws of some rehabilitation strategies. The science of these early efforts has also led to a greater understanding of selenium, wildlife diseases and pathogens, critical resource needs for maintaining fish and bird populations, and the critical role of aquatic invertebrates and microbes in the ecosystem. Scientists have begun to understand how to rehabilitate this degraded system within the constraints of less water, no new water, and degraded water as the only sources available to sustain the viability of this ecosystem while providing for the maintenance of biological diversity, avoiding toxic emissions, and ameliorating air quality concerns using less water. For adaptive management to function, scientists now must work in concert with resource managers, decisionmakers, and engineers to ensure projects are based on the best possible science.

Although initial scientific studies were done during 1998-2003, the Salton Sea ecosystem was not well understood when the QSA was implemented in 2003. Our understanding of the ecosystem is better today, but the changes scheduled for implementation at the end of 2017 could have far reaching effects on the ecology of this lake and beyond its boundaries. Since 2003, despite stakeholder meetings, expert workshops, and efforts by the State of California (California Resources Agency, 2007), little new science has been conducted and limited monitoring has occurred. During 2000-10, the Federal government submitted an Environmental Impact Statement/ Environmental Impact Report (EIS/EIR; Bureau of Reclamation, 1998), several feasibility studies were completed (Tetra Tech, 2004; Bureau of Reclamation, 2007), and the State of California submitted a Programmatic EIR/EIS (California Resources Agency, 2007). All of these activities relied heavily on the initial round of scientific investigations (for more in-depth background, see California Resources Agency, 2006, chaps. 1, 4, and 8).

Many stakeholders have advocated for no new science, recommending instead for moving forward with building management project components; however, no agreed-upon plan has been created for managing a future Salton Sea nor a definition of what constitutes "restoration" (see text box p. 1). The USGS Salton Sea Science Office has suggested that whereas there is a need to initiate construction of management project components, it is also necessary to continue to conduct science and monitoring activities concurrent to and after construction using a process known as adaptive management. Adaptive management (AM) is a structured, iterative process of decision making, with an aim to reduce uncertainty over time by continuously monitoring the system and adjusting decision-making accordingly. The AM approach recognizes 
the uncertainty of future conditions and helps protect current and future investment in these activities. Moreover, an AM approach to management requires an active science and monitoring program to provide timely analysis and feedback to managers on management program effectiveness (Williams and others, 2009; Case and others, 2013).

The USGS has led and assisted in numerous efforts focused on science of the Salton Sea (U.S. Fish and Wildlife Service, 1997) and in developing framework guidance documentation (Shipley and others, 1999) leading to the issuance of the Salton Sea Strategic Science Plan (Salton Sea Science Subcommittee, 2000). The Science Office continued in facilitating the interaction and coordination of science and management in order to support and better understand management actions. The Science Office also organized management and science leadership meetings to secure diverse input into future science and monitoring needs based on an AM approach as suggested by State and Federal managers (Bureau of Reclamation, 2007; U.S. Army Corps of Engineers and California Natural Resources Agency, 2013).

\section{Organizing Committee and State of the Salton Sea Meeting Development}

The USGS Salton Sea Science Office initiated the SoSS meeting in coordination with the University of California at Irvine (UCI), the Pacific Institute, and IID. Funding to support the State of the Salton Sea meeting and subsequent report development was provided by the Bureau of Reclamation (Reclamation), USGS, UCI, and IID. Through the Science Office, USGS provides access to decades of national and international expertise in water quality, hydrology, dust emissions, geothermal and volcano science, contaminants, and biology. Through land and water rights in Imperial County, IID is an influential stakeholder in all Salton Sea issues. The Pacific Institute, based in Oakland, Calif., is a leading nonprofit research and policy organization with long-standing involvement in the Salton Sea through active stakeholder participation and publication of several reports analyzing the consequences and costs of inaction in Salton Sea management (Cohen and others, 1999; Cohen and Hyun, 2006; Cohen, 2014). The UCI has internationally recognized expertise in many sustainability-related domains and has engaged its research, teaching, and service resources to address sustainability challenges facing the Salton Sea region.

The original idea for a State of the Salton Sea meeting of scientists arose from discussion between Doug Barnum (USGS) and Michael Cohen (Pacific Institute) and was then endorsed by USGS and U.S. Department of the Interior leadership. Representatives from UCI and IID were invited to join, and this group of individuals became the organizing committee. The support of each organizing committee member's agency was essential to the success of this venture. The combined capabilities of the organizing committee members were instrumental in working to coalesce the diverse interests of scientists, natural resource managers, and decision-makers, with a common objective of identifying science and monitoring needs for the Salton Sea.

Applied research is the type of research that is used to answer a specific question that has direct applications to solving problems. Alternately, basic research is driven purely by curiosity and a desire to expand our knowledge. Resource managers appreciate the role of basic science, but in the end they need answers to solve problems. The inherent conflict between basic and applied science is routinely expressed by resource managers and decision-makers in large-scale management projects by advising science managers to focus on "science to inform management rather than science for the sake of science." 


\section{Managerial Meetings}

A critical aspect of the renewed examination of the scientific issues at the Sea was that the organizing committee sought input from stakeholder groups, resource managers, and policy-level decision-makers prior to the SoSS meeting. These managerial meetings were held in Sacramento and El Centro, Calif., in July and August, 2014, respectively. Organizations and specific individuals were invited to solicit input from decision-makers and agency staff on key science questions that need to be addressed to ensure that habitat, air quality, and renewable energy projects at the Salton Sea are successful. Invitees were asked to help identify gaps in the current knowledge and to identify policy and project-level research needs that could be addressed by focused scientific efforts. Input from these meetings was used to develop guidance for the subsequent State of the Salton Sea meeting in which scientists were tasked with developing a research agenda and funding proposals to address the questions posed at the policy meetings. This approach was taken to specifically develop science and monitoring proposals to meet the needs identified by managers.

The organizing committee, working with stakeholders (table 2), held two 1-day managerial meetings of natural resource managers, policy-makers, and legislative aides to discuss and describe unresolved and uncertain scientific issues of Salton Sea management (table 3). These meetings were held so that stakeholders and policy-makers could talk directly with the organizing committee, express their concerns, and weigh in on science and monitoring needs. These early discussions enabled scientists to discriminate among issues for which scientific research is necessary to provide missing information and issues for which adequate scientific research is available but perhaps not adequately communicated.

The managerial meetings made use of a group agreement to put aside differences and focus on the task of identifying concerns and needs for management of the Salton Sea for the next 5 to 15 years. The aims and timeline of the meeting were agreed upon by all participants, and any objective or issues that fell beyond the scope of the current discussion were agreed to be discussed at a later time. The focus was on listening to each speaker with the belief that all participants wanted to achieve the meeting's goals. A trained facilitator was responsible for keeping participants on time and on task throughout the proceedings.

The general format of the managerial meetings included brief introductions of all participants and short presentations on the recent history of the Sea (with an emphasis on the last 15 years) to provide everyone with context and understanding of core scientific findings. Participants were then asked to briefly present their agency's concerns about the Sea and perceptions of the data needs for the Sea. Scribes captured concerns and data needs in each presentation and posted these notes on the wall, where small groups convened to discuss and digest the patterns that emerged from individual presentations. The meetings included group discussions that sought to elicit all managerial concerns but also consensus regarding the most critical knowledge gaps. A summary of information collected in these managerial meetings is included in table 3 and in greater detail in appendix 1.

Table 2. Organizational representation at the managerial meetings.

[Some organizations had multiple representatives]

\section{Organizational representation}

Bureau of Land Management

California Assembly for Water, Parks, and Wildlife

California Natural Resources Agency

California Department of Water Resources

California Department of Fish and Wildlife

Coachella Valley Water District

Defenders of Wildlife

Great Basin Air Pollution Control District

International Brotherhood Of Electrical Workers

Imperial County Air Pollution Control District

Imperial Irrigation District

Metropolitan Water District

Office of Senator Barbara Boxer

Office of Congressman Raul Ruiz

Office of Assemblyman V. Manuel Perez

Office of Congressman Juan Vargas

Riverside County

South Coast Air Quality Management District

San Diego County Water Authority

Salton Sea Authority

Sierra Club

University of California Cooperative Extension

Bureau of Reclamation

U.S. Fish and Wildlife Service

U.S. Geological Survey 
Table 3. Summary of management needs and concerns regarding science and monitoring of the Salton Sea (from appendix 2).

\begin{tabular}{|c|c|}
\hline Topic & Concerns and data needs \\
\hline Air quality & $\begin{array}{l}\text { What is the predicted consequence of a smaller lake for air quality, dust, public health, } \\
\text { plants, and agriculture? } \\
\text { How emissive is the soil and how variable is the playa? Can we predict site emissivity; } \\
\text { can we control emissivity? } \\
\text { What can we do about hydrogen sulfide emissions? }\end{array}$ \\
\hline
\end{tabular}

Data clearinghouse

There is broad support for a centralized system for ensuring that raw data, synthesized data, maps, reports, and literature are properly curated and made available for access by management, scientists, and the public.

Monitoring Gap between monitoring capacity and monitoring need.

\section{Goals and objectives of managerial meetings}

It is a rare event to have a large meeting in which natural resource managers, policy-makers, and legislative aides can have a direct dialogue with scientists on concerns and science needs for any single issue. One group tends to request that scientists adhere to recommending only ideas whereby the product is used to inform management rather than what is perceived as science for the sake of science. The other group tends to view all science as productive and is accustomed to thinking along a continuum of ideas. The State of the Salton Sea organizing committee set out to acknowledge and foster an interactive relationship of managers with scientists, using the organizing committee as the intermediary. In doing so, both groups were effectively brought together to discuss and describe unresolved and uncertain scientific issues of Salton Sea resource management. 


\section{State of the Salton Sea Meeting}

Following the managerial meetings, the organizing committee gathered scientists to discuss the current state of the scientific understanding of the Salton Sea, science and monitoring needs, and suggestions for the administration of a robust science program to provide input to an adaptive management program as management of the Sea is initiated. This SoSS meeting of scientists took place September 8-10, 2014, on the campus of University of California at Irvine at the Arnold and Mabel Beckman Center of the National Academies of Science and Engineering. The invitation only, closed session meeting format was motivated by the concern of the organizing committee for a rigorous and frank exchange of information. By having an invitation only meeting of scientists, it was the intent of the organizing committee that it should be a sciencedriven event as a means of advising managers on science and monitoring needs. Previous meetings of this nature (for example, the U.S. Fish and Wildlife Service workshop in 1997, Science Office sponsored workshops, and focused technical groups for the California Resources Agency in 2007) have met with great success using a format in which the first day focuses on reviews of science conducted to date, and then subsequent days involve expert topical-issue working groups meeting in breakout sessions to develop wide-ranging lists of critical science and monitoring needs, followed by prioritization within and among groups, estimated topical budgets, and summary writing assignments. Participants (appendix 2), a detailed description of the agenda (appendix 3), and meeting guidelines (appendix 4) are provided in appendixes to this document.

The workshop topics included biological and water resources, contaminants, air quality, carbon and algae, and socioeconomics. The selection of these broad categories was based on similar topic identification presented in earlier discussion efforts (for example, U.S. Fish and Wildlife Service, 1997; Salton Sea Science Subcommittee, 2000; Case and others, 2013). A focal point for initiating these discussions was the Salton Sea Ecosystem Monitoring and Assessment Plan (MAP; Case and others, 2013). To stimulate development of conceptual proposals, guidance was provided to scientists prior to the meeting of the types of focused investigations and monitoring needs:

- Reanalysis of inflow data and long-term modeling of lake elevation and salinity

- Endangered pupfish populations analysis and recovery strategies in a receding Sea

- Fugitive dust characterization, hot spots, treatment options, and modeling

- Integrated monitoring of invertebrates, fish, and bird populations among existing and soon-to-be-constructed wetlands
- Remote sensing technological applications supporting focused investigations and monitoring

- Groundwater modeling and assessment of availability to support management activities

- Microtargeting of selenium treatment technologies

- Investigations of algal-based solutions for carbon capture, sequestration and carbon credits

- Investigations of algal-based solutions for selenium remediation

- Investigations of bivalves as biofilters for nutrient, sediment, and selenium remediation

- Chemical composition of $\mathrm{PM}_{10}$ captured in air quality monitoring stations as related to human health and agricultural productivity

- Status of the fisheries

- Status of regional bird populations

- Water and sediment chemistries and quality

- Status of contaminants of concern, particularly selenium and current-use pesticides

After reviewing the current conditions of the Sea, the organizing committee shared with the participating scientists the concerns, needs, and data gaps identified by the managers in the two meetings in El Centro and Sacramento, Calif. It was emphasized that these needs should take priority during discussions and that conceptual proposals should be generated that address these critical needs in a timely and cost-efficient manner.

Workshop participants were placed on teams to develop conceptual proposals that addressed the needs of managers as identified in the managerial meetings. By compiling and publishing these conceptual proposals in this SoSS document, the intent is to provide managers, legislators, and other stakeholders with scientific input and direction in developing longrange plans. The document is not intended to develop funding for any specific topic, nor is it intended that any conceptual proposal is to be accepted "as is." If a comprehensive science program is developed, then these conceptual proposals may serve as the framework for implementing the science necessary to inform management decisions relative to any resource management plan devised. It is anticipated that the conceptual proposals and their estimated budgets contained herein will serve as a template for contracting of competitive awards (see appendix 4). These conceptual proposals are intended solely as brief introductions to recommended science and monitoring needs.

A future science program based on these conceptual proposals would provide geographic information system (GIS) data layers. The collection of those data layers would 
be coordinated to maximize collaboration, avoid unproductive duplication, and render the data available as quickly as possible to the many cooperators. The data would be spatially referenced so that all information could be incorporated into a model of the Salton Sea ecosystem in GIS. This Salton Sea GIS model would allow synthesis of the individual data layers into an interactive model that could evaluate complex interactive changes to the ecosystem under differently engineered projects and managed scenarios (see Case and others, 2013).

\section{Synopsis of Conceptual Proposals}

Under most future scenarios, changes to all aspects of the Salton Sea ecosystem will occur. Inflows are diminishing, nutrients and salts are increasing, selenium and pesticide contamination remain of concern and are likely to increase. Water depth, temperature, volume, and location will be altered dramatically. Salinity will induce changes to the community of aquatic invertebrates and fish, causing significant changes in population structure and abundance. Associated responses of the avian community are to be anticipated. Given the magnitude of anticipated changes to the Salton Sea ecosystem, scientists participating in the State of the Salton Sea meeting gathered and attempted to describe science and monitoring needs necessary to understand how the ecosystem will respond to these changes. By better understanding ecosystem functioning, scientists can provide support for the AM decision process.

Scientists were able to build upon previous investigations and develop a series of conceptual proposals, which will help fill voids in knowledge of the Salton Sea ecosystem (table 4, full narratives provided in appendix 5). Furthermore, a number of long-term monitoring and assessment needs supportive of an AM program were identified. Six teams covering diverse categories such as air quality, contaminants, biology, water quality and hydrology, carbon and algae, and socioeconomics produced 34 proposals with a total funding of $\$ 46,880,000$ (2015 dollars).

The 1997 workshop (U.S. Fish and Wildlife Service, 1997) yielded 39 proposals with associated funding of $\$ 36,097,600$ ( $\$ 53,443,000$ in 2015 dollars). There are many similarities between the results of the 1997 workshop and results of the 2014 State of the Salton Sea meeting in terms of issues of investigation. Much of the effort for the 1997 workshop was expended on simply understanding the "big picture" of the various components of the Sea and how these components interact. Workshop participants in 1997 were asked to prioritize their proposals, whereas time constraints precluded any such effort in the 2014 SoSS workshop. Despite the acknowledged importance at the 1997 workshop, the topic of air quality was believed at the time to be an issue that was decades into the future, compared to the urgency of understanding large-scale fish and bird mortalities, foul odors, excessive nutrients, increasing salinity, and contaminants.
There is a continued need to understand the influence of contaminants and pesticides on the ecosystem, particularly in newly constructed habitats, and the consequences of declining inflows and increasing salinity. However, the next generation of science will need to be designed to fill in identified gaps in our knowledge from previous work; this would allow better modeling of ecosystem dynamics and a better understanding of unknown effects of rehabilitation projects. Air qualityinfluenced by fugitive dust from exposed sediments and its effects on human health and the environment-is a topic the gathered scientists agreed should be a major focus of the next phase of research and monitoring. Air quality concerns are further supported by feedback from the managerial meetings, which indicated that priority should be given to initiating research on air quality investigations related to fugitive dust and associated human health issues. It should be noted that of all the options under consideration for addressing the myriad of air quality issues, water applied to maintain wet soil is a tested and proven technology, yet it may be one of the least available for implementation given the demands on limited water resources in the region. Constructed wetlands similar to the USGS/Reclamation Shallow Habitat project (Miles and others, 2009), Red Hill Bay (A.K. Miles and M.A. Ricca, unpub. data, 2011; U.S. Fish and Wildlife Service, 2014) and Species Conservation Habitat (U.S. Army Corps of Engineers and California Natural Resources Agency, 2013) may be the most efficient use of limited water supplies as they not only suppress dust but may also provide many other benefits. Despite promising research from the USGS/Reclamation Shallow Habitat project, there remain concerns as to the ability of larger constructed wetlands to avoid issues related to water quality, fish mortality, fish population sustainability, hydrogen sulfide, avian nesting and foraging, and algal blooms. Thus, while there is an urgent need for studies of air quality, there is also a need to not lose focus on the continued evaluation for total efficacy of constructed wetlands and other issues related to a reconfiguration of the Sea. Constructed wetlands within the lakebed are an important first step towards implementing Salton Sea resource management, and expectations of success run high not only for habitat value to be provided but also for air quality management to be sustained. Yet, if efficacy of constructed wetlands is not evaluated and they fail to meet expectations, then migratory bird resources remain at risk, air quality continues to degrade, and much more expensive and complex options may be required. Similarly, the ever changing water quality dynamics of this lake suggest continued monitoring and evaluation be implemented because of the important interactive and synergistic effects water quality has on many aspects of the Salton Sea ecosystem.

Time constraints of the SoSS meeting prevented the full development of several ideas. Nevertheless, the organizing committee included the title for these undeveloped ideas and a funding level suitable for addressing each conceptual proposal as part of table 4 and again in appendix 5 . 


\section{Air Quality}

The ramifications of the QSA decision of terminating mitigation water in 2017, thus accelerating exposure of Sea sediments, was a principal consideration of the meeting. A considerable amount of attention was given to proposals designed to evaluate playa exposed by receding water levels. Air quality concerns over $\mathrm{PM}_{10} / \mathrm{PM}_{2.5}$ levels, chemical composition of fugitive dust, impacts of fugitive dust on human health and agricultural productivity, and methods for suppressing fugitive dust were major topics of discussion. A new avenue of potential threat to human health lies in the propensity of water like the Salton Sea to develop assemblages of toxic cyanobacteria. Under high wind conditions, these toxins may be entrained in the mist generated by large waves and transported large distances. Perhaps a greater risk is that these toxic algae contain microcystins that remain toxic after the algae have died and been deposited on the sediments. Investigations into the potential human health risk of airborne particulate matter containing these microcystins from exposed playas could shed new emphasis on the already important issue of fugitive dust control.

\section{Water Quality}

The importance of the early limnological and water quality research simply cannot be overstated in terms of understanding not only the Sea's hydrodynamics but also the flow of nutrients, primary productivity, contaminants, and biology. With such large scale alterations of the Sea structure envisioned by most management alternatives under active consideration, it is imperative to continue with studies of water quality in order to understand how the Sea will be altered and the ramifications of those alterations on the functions of this dynamic ecosystem. With this in mind, the water-quality group developed proposals focused on modeling energy and material fluxes, water balance simulations for various sizes and configurations of a future Sea, and an adaptive management monitoring structure to facilitate and support management decisions.

\section{Contaminants}

The concerns related to contaminants, such as legacy and new generation pesticides, selenium, arsenic, and other anthropogenic pollutants remain high. The concerns remain high because many of the proposed management alternatives reviewed in the past 15 years have included components that, if implemented, could worsen the effects of these contaminants on the Salton Sea ecosystem. To avoid the unintended consequences of implementing a potentially flawed management strategy, the contaminant group recommended further research particularly on selenium and pesticides. Legacy pesticides such as DDT remain in the ecosystem, although at low levels, and have the potential to affect breeding bird populations. Likewise, little is known about other legacy pesticides and how they may affect birds, fish, or their prey items in constructed wetlands. Despite numerous expert technical workshops on selenium, managing this element to avoid adverse effects remains a significant technical and financial challenge. The contaminant group suggests additional research to quantify and evaluate biological risks to fish and bird populations.

\section{Carbon and Algae}

A group separate from the biology group was provided to consider issues related to carbon capture, carbon sequestration, and the role of algae in these ideas. Carbon uptake is an idea requiring evaluation not only for assigning monetary value to the Salton Sea for potential carbon banking but also for assessing agricultural-land carbon uptake and the potential sequestration of inorganic carbon in groundwater of saline desert systems. This in turn may provide some economic valuation in the control of greenhouse gasses and could then be measured against growth of greenhouse gasses attributed to water exports. The topic of algae farming related to biofuels production was not considered here because it is being addressed by multiple outside interests.

\section{Biology}

The biology group focused on the impacts of increasing salinity on biota in a remnant Sea and in constructed habitats. The biology group also emphasized the development of advanced models synthesizing information across multiple variables, allowing for interactive and predictive analysis of management actions. Much of the scientific effort in earlier biology investigations of the Salton Sea involved the attempt to understand existing resources, describe populations and numbers, and examine relationships to physical and chemical variables of the Sea. The biology group suggested that future investigations may be better focused on evaluating the biological functioning of constructed wetlands, biological tolerance limits to salinity, population modeling, and examining synergistic effects of critical habitat loss at the Salton Sea and elsewhere on migratory bird populations.

\section{Socioeconomics}

The emphasis of this effort lies in three integrated components: (1) equity oriented collaborative research aiming to better understand the social and cultural story of communities interacting with the Salton Sea, (2) a demographic and landuse survey aiming to identify and map land uses, and (3) an economic study to assess how management activities could impact land uses and to outline costs over time for both management and impacts on the changing economic characteristics of the communities surrounding the region. The socioeconomic group recognized that in many environmental management projects, the social sciences are largely unrecognized and thus usually receive only cursory treatment if at all. The proposal provided is an attempt to gather scientifically valid social science data on human dynamics associated with planned alterations for the Salton Sea ecosystem. 


\section{Administration}

Data storage and management, data retrieval and service to stakeholders, and archiving data and documents (cyberinfrastructure) for future generations are critical science support activities. This support for science is integral to the proper functioning of a decision-support system for management. Cyberinfrastructure is a grouping of program elements for resources necessary to integrate, assess, and prioritize data and information, an element thoroughly addressed most recently by Case and others (2013).

Through integration, scientists and decision-makers will be better able to effectively and efficiently coordinate field activities for maximum savings of time and money. In addition, the integration of protocols, standards, and practices will help assure that data will be scientifically valid and usable for the widest possible variety of assessments and uses. Integration starts in the planning phases and extends throughout the collection, interpretation, reporting, assessment, and AM parts of the restoration process.

Data assessment focuses on the query and retrieval of data stored or accessible from a centralized data-retrieval system and applying statistical and other analytical techniques to the data. This step helps to simplify the collected data, test for change and differences, develop and test hypotheses, and evaluate uncertainty. It is through rigorous assessment that progress toward restoration goals can be measured, and it is through regularly scheduled assessments that AM can be effectively implemented. A key part of any resource management plan will be the objective consideration of priorities for data collection. These priorities include immediacy (human health and safety), scientific need, management need, cost, ease, and availability of an alternative (if any).

An advantage, however, of the rigorous technical integration and assessment process is the ability to provide incentive and justification for the prioritization of activities and the efficient application and focus of stakeholder support. Priorities for integration will be guided by the overall objectives and needs identified for ecosystem restoration in general. Priorities for short-term monitoring efforts also will be strongly influenced by needs to document and assess status and trends. The highest priority questions identified by each technical focus group will be used to establish priorities within the existing available funding.

Proposal ADMIN1 provides for estimates of initial funding for these activities. A variety of plans have been developed outlining the structure of a data-management system (see Case and others, 2013; appendixes 6, 7, and 8).

\section{Recommendations for Support of an Effective Science and Monitoring Program}

One of the outcomes of the combined managerial and SoSS meetings was the realization that the Salton Sea effort is lacking a comprehensive, integrated science and monitoring program. The 1997 science-needs workshop (U.S. Fish and Wildlife Service, 1997) recognized and incorporated a series of recommendations on how best to support a large science effort. These needs were largely unmet, yet they have been identified regularly in a variety of published documents (appendixes 7 and 8). These unmet needs were once again identified in the SoSS meetings.

Future management of the Salton Sea will rely extensively on a competent and integrated science program capable of analysis, integration, synthesis, and data storage to sustain management's need for decision-support services. To address this issue, the organizing committee has provided a tabular summary of identified science support needs (table 5). Case and others (2013) provided an extensive discussion and documentation of a comprehensive, integrated monitoring program for the Salton Sea applicable to any future project design. Furthermore, a narrative discussion of an integrated science program is described in more detail in appendix 6 .

The Salton Sea project will involve a major restructuring of every component of the ecosystem over several decades. This will involve a series of complex engineering and environmental projects designed to ensure that a smaller lake with much less water can be ecologically sustainable. Development of a comprehensive cyberinfrastructure for this process can ensure that design criteria and data from these projects will be consistent among studies and available for scientists, engineers, and project managers to build upon for decades to come. The principal objectives of a cyberinfrastructure component to the Salton Sea project are to

- Establish and enforce standards for data documentation

- Establish data transfer and storage protocol

- Make data easily accessible and in a useable format

- Establish adequate program support 
Table 4. Proposal title and estimated dollar value to conduct research/monitoring activities for the Salton Sea.

[Values rounded to nearst $\$ 10,000$ and presented in 2015 dollars. —, not available]

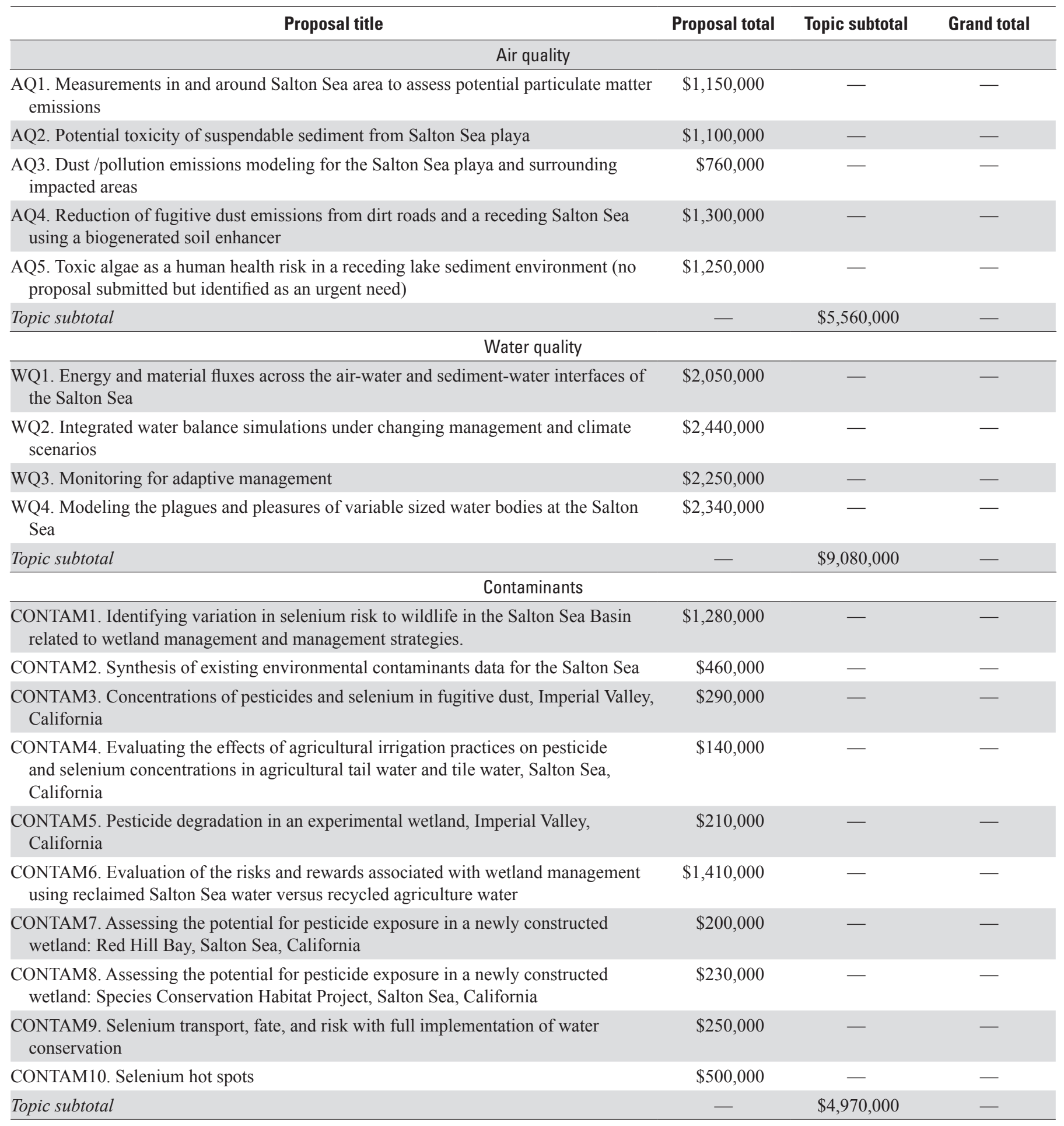


Table 4. Proposal title and estimated dollar value to conduct research/monitoring activities for the Salton Sea.—Continued

[Values rounded to nearst $\$ 10,000$ and presented in 2015 dollars. —, not available]

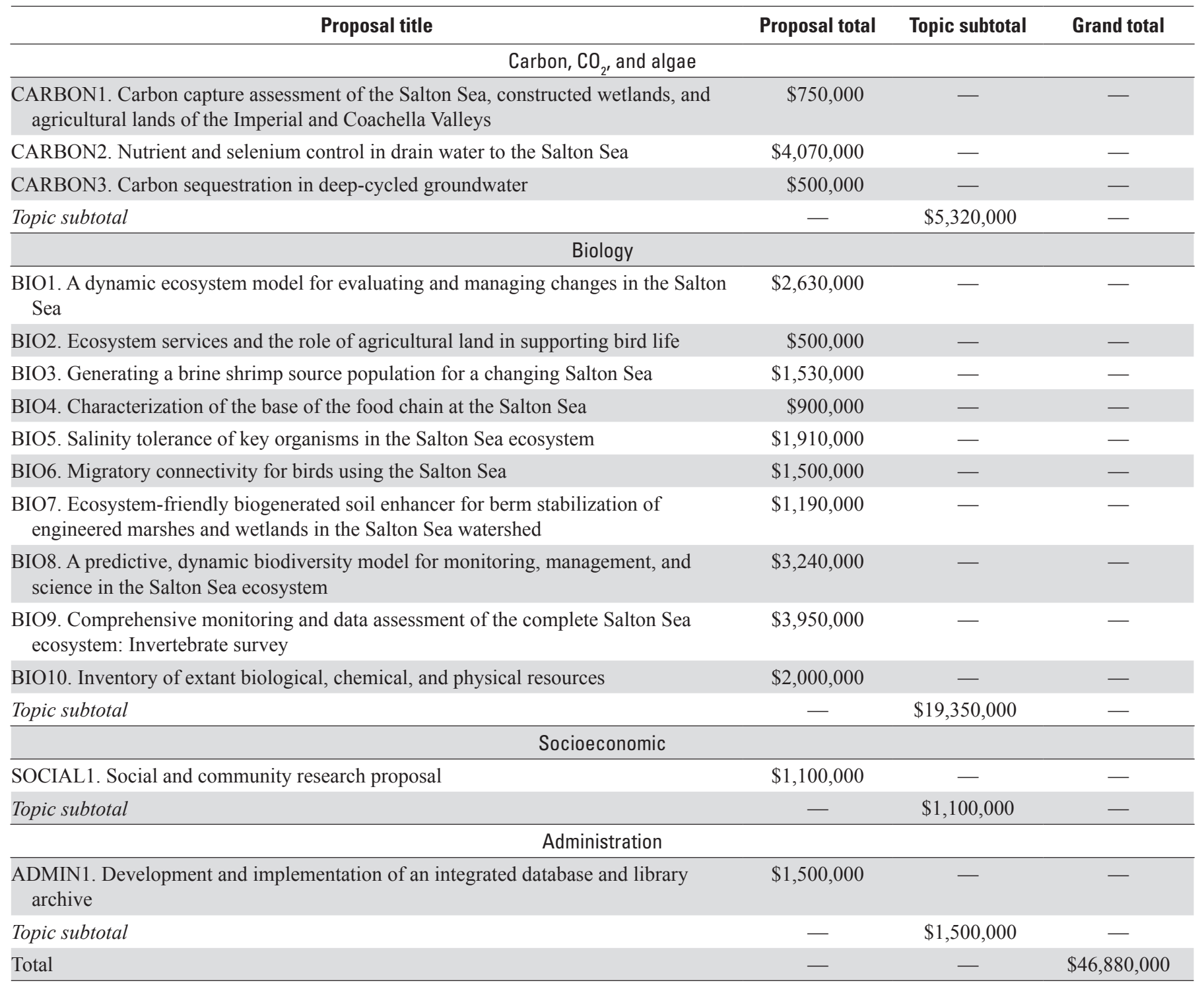


Table 5. Recommendations for support of an effective science program for the Salton Sea.

$[-$, not available $]$

\section{Suggested components required for a science program to support management decisions}

\section{Supporting document}

Component identified

and supported by

managerial meeting
Secure on-site facility with sleeping quarters, wet and dry labs, a full complement of all equipment needed for data collection and analysis to be used in common by all researchers.

The knowledge imparted through these studies would be the minimum required for well-founded decision-making with respect to both a technical project and subsequent management.

The scientists strongly recommended that protocols be established and strictly followed governing data collection techniques, sites, frequency, geographic referencing, analysis, security, availability, and integration in a geographic information system ecosystem model.

Information would be presented to the public at periodic conferences and in published conference proceedings.

An oversight team should be formed to help monitor, coordinate, and support the study efforts. Team composition should be representative of the researchers, involved agencies, and others with vested interests.

Implement a comprehensive, open scientific review process to refine the existing draft management goals and objectives from a scientific ecosystem perspective. Based on this review, agree upon performance measures as benchmarks against which to measure true success of management.

Develop and continue to refine reliable, flexible conceptual models encompassing ecosystem components and their functional relationships.

Develop a long-term ecosystem monitoring program to establish baselines, measure management outcomes, and help refine future actions.

Beyond monitoring of baseline conditions, include investigations of episodic, extreme, and unpredictable events such as fish and wildlife die-offs, algae blooms, and unusual climatic events that have the potential to significantly affect the ecosystem or influence individual valued resources.

Identify and prioritize investigations relevant to management, based on conceptual models and identified information gaps. Develop quantitative, integrative, predictive models based upon identified conceptual relationships.

Establish a data and information management program to make results of long-term monitoring and focused investigations available to resource managers, scientists, stakeholders, and the public. Funding should be adequate for sustaining long-term service at a public institution.

Establish an organizational structure and process to implement the longterm Strategic Science Plan.
U.S. Fish and Wildlife Service, 1997

-

U.S. Fish and Wildlife Service, 1997

Yes

U.S. Fish and Wildlife Service, 1997; Shipley and others, 1999; Salton Sea Science Subcommittee, 2000; Case and others, 2013; this document

U.S. Fish and Wildlife Service, 1997; Shipley and others, 1999; Salton Sea Science Subcommittee, 2000; Case and others, 2013; this document

U.S. Fish and Wildlife Service, 1997

U.S. Fish and Wildlife Service, 1997; Yes Shipley and others, 1999; Salton Sea Science Subcommittee, 2000; Case and others, 2013; this document

U.S. Fish and Wildlife Service, 1997; Shipley and others 1999; Salton Sea Science Subcommittee, 2000; Case and others, 2013; this document

Shipley and others, 1999; Salton Sea Science Subcommittee, 2000; Case and others, 2013; this document

Shipley and others, 1999; Salton Sea Science Subcommittee, 2000; Case and others, 2013; this document
Yes

Yes 


\section{Conclusion}

During late summer of 2014, State of the Salton Sea meetings were held to discuss future science and monitoring needs for the lake. Two meetings were held to gain input on managers' information needs, and a third meeting assembled science experts to develop proposals addressing those identified needs. Scientists were able to build upon previous investigations and develop a series of conceptual proposals that will help fill voids in our knowledge of the Salton Sea ecosystem. Furthermore, a number of long-term monitoring and assessment needs supportive of an adaptive management program were identified. Six teams covering diverse categories such as air quality, contaminants, biology, water quality and hydrology, carbon and algae, and socioeconomics produced 34 conceptual proposals with a total funding need of \$46,880,000 (2015 dollars). A similar workshop in 1997 yielded 39 proposals with associated funding of $\$ 36,097,600$, or about $\$ 53,443,000$ in 2015 dollars.

Feedback from the managerial meetings, combined with the sense of urgency conveyed by the gathered scientists, indicates that priority should be given to initiating research on the air quality investigations identified in this document. The focus of immediate, urgent priority is related to air quality, fugitive dust, and related human-health issues. Science conducted between 1998 and 2006 focused on ecosystem functions, enabling a much better understanding of the Salton Sea, but little research has focused on air quality as a possible variable in declining inflows to the Salton Sea. Air quality, as affected by hydrogen sulfide emissions, fugitive dust emissions increasing owing to exposure of sediments $\left(\mathrm{PM}_{10} / \mathrm{PM}_{2.5}\right.$, pesticides, and other contaminants), and related effects on human health are of increasing concern. However, the gathered scientists cautioned that there is also a need to not lose focus on the continued evaluation for total efficacy of constructed wetlands and other issues related to an anticipated large-scale reconfiguration of the Sea.

\section{References Cited}

Barnum, D.A., Elder, J.F., Stephens, Doyle, and Friend, Milton, eds., 2002, The Salton Sea - proceedings of the Salton Sea symposium, held in Desert Hot Springs, California, January 13-14, 2000: Springer Netherlands, Developments in Hydrobiology, v. 161, 306 p.

Bureau of Reclamation, 1998, Salton Sea alternatives final preappraisal report: Bureau of Reclamation, Lower Colorado Region, 108 p., accessed at https://www.usbr.gov/ lc/region/saltnsea/ssae3.html.

Bureau of Reclamation, 2007, Restoration of the Salton Sea summary report: Bureau of Reclamation, Lower Colorado Region, 179 p., accessed at https://www.usbr.gov/lc/region/ saltnsea/FinalSummaryRpt.pdf
California Resources Agency, 2006, Salton Sea ecosystem restoration program draft programmatic environmental impact report: Prepared by the California Department of Water Resources and California Department of Fish and Game for the California Resources Agency, accessed at http://www. water.ca.gov/saltonsea/peir/draft/.

California Resources Agency, 2007, Salton Sea ecosystem restoration program final programmatic environmental impact assessment: Prepared by the California Department of Water Resources and California Department of Fish and Game for the California Resources Agency, accessed at http://www. water.ca.gov/saltonsea/documents/final_eir.cfm.

Case, H.L., III; Boles, Jerry; Delgado, Arturo; Nguyen, Thang; Osugi, Doug; Barnum, D.A.; Decker, Drew; Steinberg, Steven; Steinberg, Sheila; Keene, Charles; White, Kristina; Lupo, Tom; Gen, Sheldon; and Baerenklau, K.A., 2013, Salton Sea ecosystem monitoring and assessment plan: U.S. Geological Survey Open-File Report 2013-1133, 220 p., accessed at https://pubs.usgs.gov/of/2013/1133/.

Coachella Valley Water District, Imperial Irrigation District, Metropolitan Water District of Southern California, and San Diego County Water Authority, 2002, Program environmental impact report for the implementation of the Colorado River quantification settlement agreement: State Clearinghouse no. 2000061034, v. I and II.

Cohen, M.J., 2014, Hazard's toll-The costs of inaction at the Salton Sea: Pacific Institute, $50 \mathrm{p}$.

Cohen, M.J., and Hyun, K.H., 2006, Hazard-The future of the Salton Sea with no restoration project: Pacific Institute, $60 \mathrm{p}$.

Cohen, M.J., Morrison, J.I., Glenn, E.P., 1999, Haven or hazard-The ecology and future of the Salton Sea: Pacific Institute, $78 \mathrm{p}$.

Claiborne, William, 1996, Biologists strive to save birds from lake's rest stop of death: Washington Post, accessed on September 15, 1996, at https://www.washingtonpost.com/ archive/politics/1996/09/15/biologists-strive-to-save-birdsfrom-lakes-rest-stop-of-death/c5bc5992-6faa-4568-888b70db0c9acffa/?utm_term=.baafde341ae1.

Hurlbert, S.H., ed., 2007, The Salton Sea: Lake and Reservoir Management, v. 23, no. 5, p. 467-662.

Hurlbert, S.H., ed., 2008, The Salton Sea centennial symposium; Proceedings of a symposium celebrating a century of symbiosis among agriculture, wildlife and people, 1905-2005, San Diego, Calif., March 2005: Developments in Hydrobiology, v. 201, 195 p.

Miles, A.K., Ricca, M.A., Meckstroth, Anne, and Spring, S.E., 2009, Salton Sea ecosystem monitoring project: U.S. Geological Survey Open-File Report 2009-1276, 151 p. 
Salton Sea Science Subcommittee, 2000, Strategic science plan, Salton Sea restoration project: Salton Sea Science Subcommittee, 103 p., accessed at https://www2.usgs.gov/ saltonsea/docs/history/strategic\%20sci\%20plan.pdf.

Society for Ecological Restoration International, 2004, The SER International primer on ecological restoration: Publication of the Science and Policy Working Group, accessed at http://c.ymcdn.com/sites/www.ser.org/resource/resmgr/custompages/publications/ser_publications/ser_primer.pdf?hhS earchTerms $=\% 22$ primer + and $+2002 \% 22$.

Shipley, F.S., Barnum, D.A., Black, G.F., Boarman, W.I., Duffy, W.G., Mac, M.J., Miller, D.M., Rocke, T.E., Schoeder, R.A., and Thiery, R.G., 1999, Science support for restoration of the Salton Sea; Recommendations of the USGS Tiger Team to the Salton Sea Science Subcommittee: U.S. Geological Survey Western Ecological Research Center, $34 \mathrm{p}$.

Tetra Tech, 2004, Salton Sea restoration-Development of a preferred project: Report prepared for the Salton Sea Authority, 68 p., accessed at https://www2.usgs.gov/saltonsea/docs/SSA/Pref_Project_Report2004\%20TT.pdf.

U.S. Army Corps of Engineers and California Natural Resources Agency, 2013, Salton Sea, species conservation habitat project, final environmental impact statement/environmental impact report: Prepared by the California Department of Water Resources and California Department of Fish and Game for the California Natural Resources Agency, U.S. Army Corps of Engineers Application No. SPL-201000142-LLC, State Clearinghouse No. 2010061062, 750 p., accessed at http://www.water.ca.gov/saltonsea/habitat/ eir2013.cfm.

U.S. Fish and Wildlife Service, 1997, Saving Salton Sea-A research needs assessment: U.S. Fish and Wildlife Service, $96 \mathrm{p}$.

U.S. Fish and Wildlife Service, 2014, Sonny Bono Salton Sea National Wildlife Refuge Complex; Final comprehensive conservation plan and finding of no significant impact: Federal Register, v. 79, no. 181, p. 56088-56090, accessed at https://www.federalregister.gov/articles/2014/09/18/2014-22272/sonny-bono-salton-seanational-wildlife-refuge-complex-final-comprehensiveconservation-plan-and.

Williams, B.K., Szaro, R.C., and Shapiro, C.D., 2009, Adaptive management-The U.S. Department of the Interior technical guide: Adaptive management working group: U.S. Department of the Interior, $84 \mathrm{p}$. 
Prepared by the Sacramento Publishing Service Center.

For more information concerning this report, contact:

Pacific Regional Director

U.S. Geological Survey

$6000 \mathrm{~J}$ Street, Placer Hall

Suite 5000

Sacramento, CA 95819

or visit our Web site at:

https://www.usgs.gov/science/regions/pacific 


\section{$\frac{\mathbb{2}}{8}$}

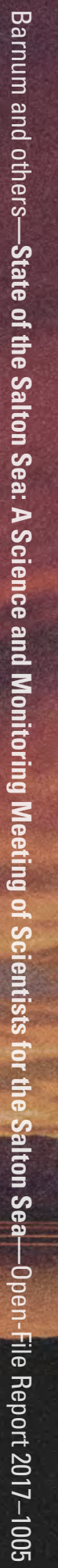

